\title{
Enzootic instability for bovine anaplasmosis on family farms located in southwestern Paraná, Brazil
}

\author{
Instabilidade enzoótica para anaplasmose bovina em propriedades de agricultura familiar do \\ sudoeste paranaense, Brasil
}

Tatiane Sott ${ }^{1}$; Carina Franciscato ${ }^{1}$; Adolfo Firmino da Silva Neto ${ }^{1}$; Iucif Abrão Nascif Júnior ${ }^{1}$;

Fagner Luiz da Costa Freitas ${ }^{1 *}$

${ }^{1}$ Laboratório de Saúde Única, Universidade Federal da Fronteira Sul - UFFS, Realeza, PR, Brasil

Received March 30, 2016

Accepted June 21, 2016

\begin{abstract}
The objective of this study was to assess the occurence of animals seropositive for Anaplasma marginale in the municipality of Realeza, Paraná State, Brazil. Blood samples were collected from 344 cows on 18 small farms in the municipality of Realeza-PR. The animals'serum samples were forwarded to the Federal University of Fronteira do Sul, in order to investigate the occurrence of anti- $A$. marginale $\operatorname{IgG}$ antibodies by an enzyme-linked immunosorbent assay commercial kit. IgG antibodies to $A$. marginale were detected in cattle from $77.7 \%$ of the farms. To the best author's knowledge, this is the first report of occurrence of $A$. marginale in cattle in southwestern Paraná. The serological assay showed that $24.4 \%$ of the animals were seropositive, thus characterizing the location investigated as an area of enzootic instability for the disease. The family farms located in the municipality of Realeza-PR showed enzootic instability for bovine anaplasmosis. It is necessary to conduct disease monitoring programs in association with preventive measures in order to ensure the sanitary quality of the herds and to reduce economic losses for the farmers. In addition, it is essential to implement educational extension actions that allow farmers to acquire knowledge, attitudes and perceptions regarding the risk factors that contribute towards herd $A$. marginale-infection.
\end{abstract}

Keywords: Anaplasma marginale, epidemiology, seroprevalence.

\section{Resumo}

O objetivo deste estudo foi avaliar a ocorrência de animais soropositivos para Anaplasma marginale, no município de Realeza, Estado do Paraná, Brasil. Foram colhidas amostras de sangue de 344 fêmeas bovinas provenientes de 18 propriedades rurais do município de Realeza - PR. Amostras de soro dos animais foram encaminhadas à Universidade Federal da Fronteira Sul, para realização do Ensaio Imunoenzimático Indireto para pesquisa de anticorpos IgG anti- Anaplasma marginale por meio de kit comercial. Anticorpos IG anti-A. marginale foram detectados em $77,7 \%$ das propriedades. Trata-se do primeiro registro da ocorrência de $A$. marginale no Sudoeste paranaense. A sorologia evidenciou $24,4 \%$ de animais soropositivos, caracterizando o local pesquisado como área de instabilidade enzoótica para a doença. As propriedades de agricultura familiar, localizadas no município de Realeza-PR, apresentaram instabilidade enzoótica para anaplasmose bovina. É necessário que programas de monitoramento da enfermidade sejam realizados em conjunto com medidas de prevenção, visando garantir qualidade sanitária do rebanho e reduzir perdas econômicas dos produtores rurais. Além disso, é fundamental a realização de açóes de extensão que viabilizem a aquisição de conhecimento, atitude e percepção dos criadores diante dos fatores de risco contribuintes para a infecção por $A$. marginale do rebanho.

Palavras-chave: Anaplasma marginale, epidemiologia, soroprevalência.

Dairy cattle-rearing is a prominent agricultural activity in the state of Paraná and is responsible for generating a significant portion of the monthly income of agricultural households. However, the investments and technological advances used in this activity over the years have not been sufficient to prevent the presence of

*Corresponding author: Fagner Luiz da Costa Freitas. Laboratório de Saúde Única, Universidade Federal da Fronteira Sul - UFFS, Rua Edmundo Gaievsk, 1000, Cidade Universitária, CEP 85770-000, Realeza, PR, Brasil.

e-mail: fagner.freitas@uffs.edu.br pathogens capable of causing economic and production losses relating to dairy herds. Among these, bacteria belonging to the genus Anaplasma genus can be highlighted, since this agent is responsible for causing anaplasmosis in cattle (OIE, 2016).

Anaplasma marginale is transmitted by the Rhipicephalus (Boophilus) microplus tick, fomites and through bites from Stomoxys calcitrans, Haematobia irritans and congenitally (GONÇALVES, 2000). The clinical condition of the infected animals is characterized mainly by hyperthermia, anorexia, tachycardia, tachypnea, pale or icteric 
mucosae, lethargy, prostration, reduced rumination movements, decreased milk production and abortion, resulting from hemolysis and anoxia (VIDOTTO et al., 2006). Consequently, productivity and income obtained from the dairy business are compromised due to the presence of this disease in the herd. Expenditure on drugs and specialized professionals is required, and the disease can cause reduction in milk production, temporary infertility in males and females, abortions and death (SOUZA et al., 2001).

Occurrence of bovine anaplasmosis is directly associated to climatic and management characteristics that enable or hinder the survival of the vectors (COSTA et al., 2013). Higher incidence is seen particularly in regions with tropical or subtropical climates (OIE, 2016), in which also contribute to infection with Babesia species. In Brazil, the climatic characteristics vary greatly (GONÇALVES, 2000), such that the epidemiological situation of the babesiosis is classified into three groups: unstable areas, where the prevalence is between 20 and $75 \%$; stable areas, where the prevalence is greater than or equal to $75 \%$; and free areas where the survival of biological vectors is not possible (MAHONEY \& ROSS, 1972).

Agricultural and livestock production from small producers in Brazil is referred to as family agriculture. This type of activity is an important factor in promoting social equality, economic development and actions that promote more rational and sustainable use of natural resources. In the southwest region of the state of Paraná, where this study was developed, family agriculture has been strongly associated with milk production. In addition, the geographic location, bordering the neighboring country of Argentina, confers strategic importance on this region from the zoosanitary point of view.

However, the systematic information available on the health of the dairy herds of this region is scarce, which hampers health monitoring, and consequently preventive and epidemiological surveillance actions, especially in relation to diseases that are not subject to government control programs. For this reason and because of the specific characteristics of anaplasmosis, this disease is of great epidemiological importance within this scenario. Affected animals do not show clinical signs after the initial phase of the infection, and it is not possible to detect the pathogen through conventional diagnostic methods. Thus, animals carrying the pathogen remain in the environment, which increases the risk of transmission (VIDOTTO \& MARANA, 2001).

The objective of this study was to assess the occurrence of antibodies to $A$. marginale in cattle in the municipality of Realeza, southwestern Paraná.

This study was approved by the Ethics Committee on the Use of Animals (CEUA) (protocol 23205.003294 / 2014-98) and the farmers and researchers signed an free and informed consent statement. Following this, blood samples were collected from 344 cows of milk-yielding breeds ( 310 Holstein-Friesian, 13 Jersey, 19 Holstein-Friesian/Jersey crossbreds, one Holstein-Friesian/ Gir crossbred and one Holstein-Friesian/Brown Swiss crossbred) over the age of one year, on 18 small farms that were chosen by convenience in the municipality of Realeza-PR $\left(25^{\circ} 46^{\prime} 01^{\prime \prime} \mathrm{S}\right.$ $\left.53^{\circ} 31^{\prime} 37^{\prime} \mathrm{W}\right)$. During the sample collection, which was done between May and August 2015, the farmers were asked about some features of their farms and about the individuals who were responsible for dairy activities and management.
Blood samples were taken from the coccygeal vein using sterile, disposable needles of dimensions $40 \times 12$ millimeters, which were attached to glass tubes under vacuum and without anticoagulant. The tubes were identified with the ear tag number, breed and age of the animal and the owner's name. The tubes were placed in Styrofoam boxes with ice and were sent to the Clinical Analysis Laboratory of the Superintendency Unit of the University Veterinary Hospital (SUHVU) of the Federal University of Fronteira do Sul (UFFS). In the laboratory, the tubes were centrifuged at 3,000 rpm for 10 minutes. After centrifugation, the serum was stored in Eppendorf microtubes, which were placed in an the ultra-freezer at a temperature of $-45^{\circ} \mathrm{C}$. Subsequently, the animals' serum samples were forwarded to the UFFS One Health Laboratory in order to detect IgG antibodies to $A$. marginale by a commercial Enzyme-linked immunosorbent assay (ELISA) (Imunodot Diagnostics, Jaboticabal, BR). The preparations and procedures used followed the directions of the instruction manual for the product. At the end of the procedure, the plates were read using an ELISA microplate reader (Multiskan GO UV/VIS spectrophotometer; Thermo Scientific) with a $405 \mathrm{~nm}$ filter. The results were obtained by calculating the cutoff index, optical density (OD) and sample coloration, as indicated in the instruction manual. Samples that presented an intense yellow color and OD greater than or equal to the cutoff index were considered to be positive for $A$. marginale, while samples that showed no intense yellow color and OD lower than the cutoff index were considered negative.

The number of animals diagnosed as positive through the ELISA serological test was used as a parameter for classifying the area as one of enzootic instability or stability. This classification followed the conditions proposed by Mahoney \& Ross (1972) to bovine babesiosis, in which areas of stability are those where the number of positive animals exceeds $75 \%$ of the total sample, while areas of instability are those where the positive animals represent less than $75 \%$ of the sample.

In order to evaluate the association between risk factors and exposure to the pathogen, a univariate analysis using the chi-square test and Odds Ratio (OR) with 95\% confidence interval was performed. The calculations were performed using the Statcalc from Epi Info ${ }^{\mathrm{TM}}$ software, version 7.2.0.1.

\section{Results and Discussion}

Herein, antibodies to $A$. marginale were detected in $77.7 \%$ of the farms, representing the first report of occurrence of $A$. marginale in southwestern Paraná. The serological evaluation showed that $24.4 \%$ of the animals were reactive, thus characterizing the location investigated as an area of enzootic instability for the disease, with seropositivity ranging from $5 \%$ to $60 \%$ on the positive farms (Table 1).

Table 2 presents the main risk factors possible associated to the occurrence of antibodies to $A$. marginale in cattle on sampled family farms. Most of the owners were over 30 years of age and had a low education level. Dairy farming was the main source of income of the farms, although odds ratio didn't show sufficient strength to establish an association. The use of antiparasitic drugs without veterinary prescription in situations of high ticks and 
Table 1. Seroprevalence of Anaplasma marginale on family farms in the municipality of Realeza, state of Paraná, Brazil, 2016.

\begin{tabular}{|c|c|c|c|c|c|c|c|}
\hline \multirow{3}{*}{$\begin{array}{c}\text { Rural } \\
\text { properties }\end{array}$} & \multirow{3}{*}{$\begin{array}{l}\text { Number of } \\
\text { animals } \\
\text { examined }\end{array}$} & \multirow{3}{*}{$\begin{array}{l}\text { Frequency of } \\
\text { IgG antibodies } \\
\text { to } A \text {. marginale } \\
(\%) \\
\end{array}$} & \multirow{3}{*}{ Reaction cut-off } & \multicolumn{4}{|c|}{ Optical density (D.O) } \\
\hline & & & & \multicolumn{2}{|c|}{ Positive animals } & \multicolumn{2}{|c|}{ Negative animals } \\
\hline & & & & Mean & $\begin{array}{c}\text { Variation } \\
(\min -\max )\end{array}$ & Mean & $\begin{array}{c}\text { Variation } \\
(\mathrm{min}-\mathrm{max})\end{array}$ \\
\hline 1 & 18 & $50.0 \%$ & \multirow{4}{*}{1.18375} & 1.68 & $1.198-2.384$ & 0.914 & $0.706-1.133$ \\
\hline 2 & 20 & $15.0 \%$ & & 1.38 & $1.209-1.520$ & 0.878 & $0.610-1.163$ \\
\hline 3 & 24 & $25.0 \%$ & & 1.38 & $1.219-1.622$ & 0.920 & $0.701-1.162$ \\
\hline 4 & 12 & $50.0 \%$ & & 1.38 & $1.195-1.522$ & 0.996 & $0.818-1.140$ \\
\hline 5 & 20 & $40.0 \%$ & \multirow{5}{*}{1.54875} & 1.83 & $1.554-2.710$ & 1.150 & $0.740-1.483$ \\
\hline 6 & 15 & $13.3 \%$ & & 1.54 & $1.545-1.546$ & 1.193 & $0.896-1.526$ \\
\hline 7 & 20 & $5.00 \%$ & & 1.81 & $1.814-1.814$ & 1.061 & $0.715-1.465$ \\
\hline 8 & 20 & $40.0 \%$ & & 1.86 & $1.595-2.316$ & 1.167 & $1.014-1.533$ \\
\hline 9 & 20 & $60.0 \%$ & & 2.05 & $1.633-3.504$ & 1.009 & $0.615-1.294$ \\
\hline 10 & 32 & $43.7 \%$ & \multirow{4}{*}{1.36750} & 1.66 & $1.383-2.467$ & 1.033 & $0.427-1.293$ \\
\hline 11 & 19 & $21.0 \%$ & & 1.45 & $1.366-1.554$ & 1.019 & $0.689-1.304$ \\
\hline 12 & 20 & $30.0 \%$ & & 1.53 & $1.371-1.797$ & 1.043 & $0.810-1.227$ \\
\hline 13 & 18 & $5.50 \%$ & & 1.48 & $1.483-1.483$ & 0.915 & $0.491-1.337$ \\
\hline 14 & 23 & $17.4 \%$ & \multirow{5}{*}{1.65750} & 2.24 & $1.757-2.570$ & 0.935 & $0.424-1.445$ \\
\hline 15 & 15 & $0.00 \%$ & & 0.0 & 0.0 & 0.981 & $0.785-1.546$ \\
\hline 16 & 18 & $0.00 \%$ & & 0.0 & 0.0 & 0.820 & $0.491-1.507$ \\
\hline 17 & 10 & $0.00 \%$ & & 0.0 & 0.0 & 0.894 & $0.701-1.112$ \\
\hline 18 & 20 & $0.00 \%$ & & 0.0 & 0.0 & 1.003 & $0.594-1.592$ \\
\hline
\end{tabular}

Table 2. Risk factors associated to the occurrence of IgG antibodies to $A$. marginale on family farms in the municipality of Realeza, state of Paraná, Brazil, 2016.

\begin{tabular}{|c|c|c|c|}
\hline Risk factors & $(\%)$ & OR & $\chi^{2}$ \\
\hline \multicolumn{4}{|c|}{ Age group responsible for dairy farming } \\
\hline 0 to 20 & 5.5 & * & - \\
\hline 20 to 30 & 5.5 & * & - \\
\hline 30 to 40 & 27.7 & 0.45 & 0.51 \\
\hline 40 to 50 & 27.7 & 1.77 & 0.20 \\
\hline Over 50 & 33.3 & 0.66 & 0.13 \\
\hline \multicolumn{4}{|c|}{ Educational level of responsible for dairy farming } \\
\hline Basic education & 83.4 & * & - \\
\hline Incomplete high school & 5.5 & $*$ & - \\
\hline High school & 11.1 & * & - \\
\hline \multicolumn{4}{|l|}{ Main source of income from property } \\
\hline Dairy farming & 88.9 & * & - \\
\hline Agriculture & 11.1 & $*$ & - \\
\hline \multicolumn{4}{|l|}{ Parasites identified in the herd } \\
\hline Ticks & 100 & $\$$ & - \\
\hline Flies & 55.5 & $s$ & - \\
\hline \multicolumn{4}{|l|}{ Parasite control } \\
\hline Strategic control & 11.1 & $*$ & - \\
\hline Curative control & 83.4 & $*$ & - \\
\hline Aleatory control & 5.5 & * & - \\
\hline \multicolumn{4}{|c|}{ Interval between treatments with acaricides } \\
\hline 15-30 days & 11.1 & * & - \\
\hline 30-60 days & 5.5 & $*$ & - \\
\hline$>60$ days & 83.4 & * & - \\
\hline \multicolumn{4}{|l|}{ Service used } \\
\hline Veterinarian & 77.7 & $s$ & - \\
\hline Farmer & 100 & $s$ & - \\
\hline
\end{tabular}

* The Odds Ratios result is zero; $₫$ The exposure factor is present in more than one situation. 
flies infestation (curative control), possibly, contributed towards the occurrence of $\mathrm{IgG}$ antibodies to $A$. marginale on the family farms evaluated in this study, despite the fact that this was not statistically supported.

The risk factors observed in this study may contribute to outbreaks and high mortality rate in the herd in case of prolonged use of acaricides, exploited breed and infestation level (MAHONEY $\&$ ROSS, 1972). In the latter case, in order to control S. calcitrans, $H$. irritans and $R$. (B) microplus infestations is essential to maintain populations at acceptable levels that do not cause economic losses to dairy farms, enabling a balance in host-parasite relationship.

Until the present date, few regions of Brazil have been identified as areas of instability for $A$. marginale. Although European breeds are susceptible to infestations and parasitic infections (AZEVEDO et al., 2008), the occurrence of antibodies to $A$. marginale found in the present study was lower than that observed in other regions of Brazil. Studies performed in the State of Rio de Janeiro, southeastern Brazilian territory, showed an occurrence of antibodies to $A$. marginale ranging between $91.16 \%$ (SOUZA et al., 2000) and 98.21\% (SOUZA et al., 2001). In the state of Bahia, northeastern Brazilian territory, a seropositivity of 94.8\% was reported in cattle (BARROS et al., 2005). In other municipalities in the State of Paraná, antibodies anti-A.marginale were observed in $92.94 \%$ of cattle from Londrina (ANDRADE et al., 2001), 76.1\% in Umuarama (YOSHIHARA et al., 2003) and $58.74 \%$ in Ponta Grossa, Guarapuava and Laranjeiras do Sul cities (MARANA et al., 2009).

The fact that the municipality of Realeza, Paraná, is geographically located close to the border with Argentina emphasizes the need to monitor $A$. marginale infection in cattle, especially because of the possibility of illegal trade of animals through river crossings, which consequently may make disease control in Brazil difficult.

\section{Conclusion}

The family farms located in the municipality of Realeza, Paraná, showed enzootic instability for bovine anaplasmosis. Given the data presented, it is necessary to conduct disease monitoring programs in conjunction with preventive measures in order to ensure the sanitary quality of the herds and to reduce economic losses for the farmers. In addition, it is essential to implement educational extension actions that allow farmers to acquire knowledge, attitudes and perceptions regarding the risk factors that contribute towards herd A.marginale infection.

\section{References}

Andrade GM, Vidotto O, Vidotto MC, Yoshihara E, Kano FS, Amaral CHS. Soroprevalência de Anaplasma marginale em bovinos leiteiros e estudos sobre a dinâmica da infecção natural em bezerros holandeses no Sul do Brasil. Semina: Cienc Agrár 2001; 22(2): 155-159.
Azevêdo DMMR, Alves AA, Sales RO. Principais ecto e endoparasitas que acometem bovinos leiteiros no Brasil: uma revisão. Rev Bras Hig Sanid Anim 2008; 2(1): 43-55.

Barros SL, Madruga CR, Araújo FR, Menk CF, Almeida MA, Melo EPS, et al. Serological survey of Babesia bovis, Babesia bigemina and Anaplasma marginale antibodies in cattle from the semi-arid region of the state of Bahia, Brazil, by enzyme-linked immunosorbent assays. Mem Inst Oswaldo Cruz 2005; 100(6): 513-517. PMid:16302060. http://dx.doi. org/10.1590/S0074-02762005000600003

Costa VMM, Ribeiro MFB, Duarte ALL, Mangueira JM, Pessoa AFA, Azevedo SS, et al. Seroprevalence and risk factors for cattle anaplasmosis, babesiosis, and trypanosomiasis in a Brazilian semiarid region. Rev Bras Parasitol Vet 2013; 22(2): 207-213. PMid:23802235. http://dx.doi. org/10.1590/S1984-29612013005000022.

Gonçalves PM. Epidemiologia e controle da tristeza parasitária bovina na regiáo Sudeste do Brasil. Cienc Rural 2000; 30(1): 187-194. http:// dx.doi.org/10.1590/S0103-84782000000100030.

Mahoney DF, Ross DR. Epizootiological factors in the control of bovine babesiosis. Aust Vet J 1972; 48(5): 292-298. PMid:4672119. http:// dx.doi.org/10.1111/j.1751-0813.1972.tb05160.x.

Marana ERM, Dias JA, Freire RL, Vicentini JC, Vidotto MC, Vidotto O. Soroprevalência de Anaplasma marginale em bovinos da região Centro-Sul do estado do Paraná, Brasil, por um teste imunoenzimático competitivo utilizando proteína recombinante MSP5-PR1. Rev Bras Parasitol Vet 2009; 18(1): 20-26. PMid:19500456. http://dx.doi. org/10.4322/rbpv.01801004.

Souza JCP, Soares CO, Madruga CR, Massard CL. Prevalência de anticorpos anti-Anaplasma marginale (Rickettsiales: Anaplasmataceae) em bovinos na mesorregião do médio Paraíba. Cienc Rural 2001; 31(2): 309-314. http://dx.doi.org/10.1590/S0103-84782001000200019.

Souza JCP, Soares CO, Massard CL, Scofield A, Fonseca AH. Seroprevalence of Anaplasma marginale in cattle in the Norte Fluminense mesoregion. Pesq Vet Bras 2000; 20(3): 97-101. http://dx.doi.org/10.1590/S0100736X2000000300002.

Vidotto MC, Kano SF, Gregori F, Headley SA, Vidotto O. Phylogenetic analysis of Anaplasma marginale strains from Paraná State, Brazil, using the $m s p 1 \alpha$ and $m s p 4$ genes. J Vet Med B 2006; 53(9): 404-411. PMid:17062116. http://dx.doi.org/10.1111/j.1439-0450.2006.00984.x.

Vidotto O, Marana ERM. Diagnóstico em Anaplasmose bovina. Cienc Rural 2001; 31(2): 361-368. http://dx.doi.org/10.1590/S010384782001000200028 .

World Organisation for Animal Health - OIE. Bovine Anaplasmosis [online]. Paris: OIE; 2016 [cited 2016 Jul 20]. Available from: http:// www.oie.int/fileadmin/Home/eng/Health_standards/tahm/ 2.04.01_ BOVINE_ANAPLASMOSIS.pdf

Yoshihara E, Vidotto O, Yamamura MH, Marana ERM, Pacheco R, Silveira AP. Studies of natural infection with Anaplasma marginale in Nelore cattle in the Umuarama Municipality, Paraná State, Brazil. Rev Bras Parasitol Vet 2003; 12(1): 21-26. 